\title{
Stable strontium in human bone: geographical and age differences in the United Kingdom and their correlation with levels of strontium-90
}

\author{
By R. H. MOLE \\ Medical Research Council Radiobiological Research Unit, Harwell, Didcot, Berks.
}

$$
\text { (Received } 7 \text { April 1964-Accepted } 23 \text { September 1964) }
$$

The levels of stable strontium (principally ${ }^{88} \mathrm{Sr}$ ) in human tissues are now of some importance for two reasons. In investigation of bone disorders and of rates of calcification in man stable Sr has been used as a tracer for calcium in order to avoid the inevitable, if small, radiation dose to tissue which follows the use of radioactive Ca (Fraser, Harrison \& Ibbertson, 1960). Secondly, when considering the uptake into the skeleton and turnover within the body of the ${ }^{90} \mathrm{Sr}$ derived from fallout, it has been realized that these must depend more closely on the behaviour of stable Sr than of $\mathrm{Ca}$ since there is some physiological discrimination between the two elements during intestinal absorption, renal excretion and milk secretion and across the placenta (Bryant \& Loutit, I96r, I964).

Numerous analyses have been made of the stable $\mathrm{Sr}$ in human bone ash in various countries, and results with British specimens have been issued in a series of reports (Bryant, Chamberlain, Morgan \& Spicer, I957; Bryant, Henderson, Spicer \& Webb 1958; Bryant, Henderson, Spicer, Webb \& Webber, I959; Bryant, Cotterill, Henderson, Spicer \& Webber, I959; Arden, Bryant, Henderson, Lloyd \& Morgan, 1960; Bryant, Henderson, Lee, Lloyd \& Webb, I96o; Graham, Lenihan, Macdonald \& Warren, I960; Bryant, Henderson, Jones, Lee, Lloyd \& Wordingham, I96r ; Bryant, Henderson, Lee, Sweeney \& Webb, I96r; Bryant, Henderson, Lee, Parker, Sweeney \& Webb, 1962; Bryant, Henderson, Jenkins, Jury, Parker \& Wordingham, 1962; Bartlett, Bryant \& Loutit, 1963; Bryant, Henderson, Jury, Parker, Sweeney \& Webber, 1963; Bryant, Henderson, Jury, Morton, Parker \& Webber, 1963, 1964). A difference between neonatal specimens from London and from Lancashire and Wales has already been noted (Bryant \& Loutit, I964). A more detailed review of the data has now shown wider geographical differences within the United Kingdom and also a geographical difference in the change in concentration with age. In newborn infants there may also be variations with season of the year and with mode of death. During infancy and childhood there seems to be an inverse correlation between the levels of ${ }^{90} \mathrm{Sr}$ and stable $\mathrm{Sr}$ in bone when comparisons are made over wide geographical areas. A worldwide survey of stable $\mathrm{Sr}$ in bone has already been made (Thurber, Kulp, Hodges, Gast \& Wampler, 1958) but this paper is confined to British data. 


\section{EXPERIMENTAL}

The analytical methods have been described by those who made the estimations (Jury, Webb \& Webb, 1960; Webb \& Wordingham, 1963). All the values for stable $\mathrm{Sr}$ are given as concentrations of stable $\mathrm{Sr}$ relative to $\mathrm{Ca}(\mu \mathrm{g} / \mathrm{g})$ in bone ash. The anatomical origin of the bone is given for each assay in the reports already cited. The femur in whole or in part was by far the commonest. Sometimes the bones of two or more individuals were combined into one specimen for analysis: these results have been ignored except in one instance (second footnote, $\uparrow$, Table 1 ).

When calculating means and standard errors of grouped data an individual result has sometimes been omitted, which is always stated in footnotes in the tables. An omission was made, not because there was any reason to doubt the result in question, but because the omitted result was so different from the others in its group that its inclusion might possibly mislead by exaggerating the difference between the group in question and the general mean. The information given in the tables allows the calculation of the mean and standard error of a group when a result is not omitted.

The geographical origin of each specimen is given in the reports already cited, but usually only in general terms according to county. The more detailed information required for the present purpose was obtained by reference to the original documents which accompanied the bone specimens. In this paper analytical results were used only for subjects whose home address was known.

\section{RESULTS}

Since deaths in children after the perinatal period are normally so rare, bones from individuals with uncommon disorders, such as hydrocephalus, made up a high proportion of all analyses in children. Leukaemia at all ages and Paget's disease at advanced ages occurred far more often than their general incidence in the living or indeed amongst deaths. No systematic variation of stable $\mathrm{Sr}$ levels with any particular diagnostic category was found except in one case which will be discussed later.

It should be emphasized that whenever the term 'level' or 'concentration' is used it is to be understood merely as a shorthand expression for ratio in bone: the usage is justified because $\mathrm{Ca}$ forms a hardly varying proportion of bone ash.

No analyses of adult bones were available from Scotland or Wales and the data from England will therefore be considered first.

\section{Geographical variation in adult bones (2I years and more) in England}

Inspection and mapping showed that there were distinct differences between different parts of England, sometimes over quite short distances. Stable Sr levels were around $250 \mu \mathrm{g} / \mathrm{g}$ over wide areas of the country, but were much higher in the north-west and the south-east (Table I). In the south-east the Sr level was around $350 \mu \mathrm{g} / \mathrm{g}$ both in London and its surrounding counties and in an area called for convenience Thames Valley. Cumberland as a whole showed even higher values (Table I) and there was a clear distinction between Carlisle and its immediate environs 


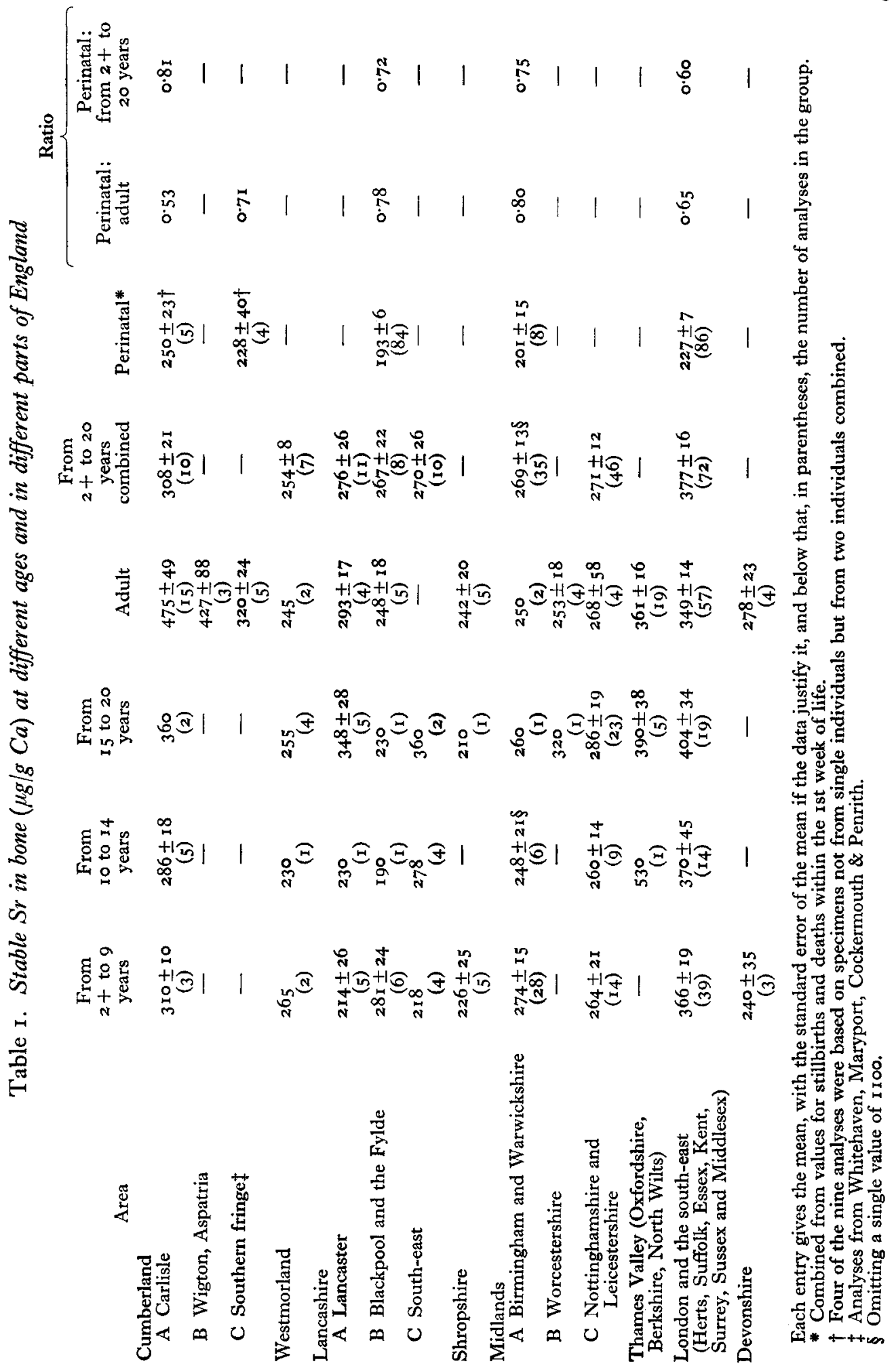


(Cumberland A $475 \mu \mathrm{g} / \mathrm{g}$ ) and a belt of country $20-30$ miles away running in a crescent east and west at the foot of the hill country (Cumberland $\mathrm{C}_{320} \mu \mathrm{g} / \mathrm{g}$ ). Another 20 miles further south in the hilly Lake District the values were around $25 \% \mu \mathrm{g} / \mathrm{g}$, the same as in the flat country of the Fylde, Lancashire. Lancaster, however, between the Lake District and the Fylde, seemed to have appreciably higher levels than the Fylde itself $(P<0.0$ I by $t$ test for differences between means of combined data for from 15 to 20 years and for adult groups).

Isolated analyses in northern England gave the following results: Thornaby-onTees, North Riding, adult, $45 \% \mu \mathrm{g} / \mathrm{g}$; Halton-le-gate, Northumberland, I 3 years old, $440 \mu \mathrm{g} / \mathrm{g}$; Tweedmouth, Northumberland, 2 years 6 months, $430 \mu \mathrm{g} / \mathrm{g}$; Brampton, Northumberland, stillbirth, $4 \mathrm{ro} \mu \mathrm{g} / \mathrm{g}$; and just over the border in southern Scotland, Newcastleton in Roxburghshire, adult, $440 \mu \mathrm{g} / \mathrm{g}$; and Thankerton in southern Lanarkshire, 7 years old, $400 \mu \mathrm{g} / \mathrm{g}$. This evidence suggests that some common factor responsible for a high level of stable $\mathrm{Sr}$ in bone is to be found right across northern England from west to east and perhaps also in south-eastern Scotland.

Mapping of the analyses for children and adults from the Midlands suggests that there is a small tract of country between Derby, Leicester and Nottingham which gives analytical results in the London range (seven results, age 7-33 years, range $270-600$, mean $443 \pm 44 \mu \mathrm{g} / \mathrm{g}$ ). These possible geographical variations should be borne in mind when considering whether there are real changes in Sr over the age range from 2 to 20 years.

Table 2. Stable Sr levels in bone $(\mu \mathrm{g} / \mathrm{g} \mathrm{Ca})$ from adults of different ages

\begin{tabular}{|c|c|c|c|c|c|c|}
\hline Area (see Table I) & $\begin{array}{l}\text { From } \\
\text { ro to } 14 \\
\text { years }\end{array}$ & $\begin{array}{c}\text { From } \\
15 \text { to } 20 \\
\text { years }\end{array}$ & $\begin{array}{c}\text { From } \\
21 \text { to } 39 \\
\text { years }\end{array}$ & $\begin{array}{c}\text { From } \\
40 \text { to } 49 \\
\text { years }\end{array}$ & $\begin{array}{c}\text { From } \\
50 \text { to } 59 \\
\text { years }\end{array}$ & $\begin{array}{l}\text { From } \\
60 \text { to } 69 \\
\text { years }\end{array}$ \\
\hline London and south-east & $\begin{array}{r}370 \\
\pm 45 \\
(I 4)\end{array}$ & $\begin{array}{r}404 \\
\pm 34 \\
(19)\end{array}$ & $\begin{array}{r}362 \\
\pm 25 \\
(13)\end{array}$ & $\begin{array}{r}369 \\
\pm 49 \\
(13)\end{array}$ & $\begin{array}{r}346 \\
\pm 19 \\
\text { (10) }\end{array}$ & $\begin{array}{r}327 \\
\pm 19 \\
(12)\end{array}$ \\
\hline Thames Valley & & $\begin{array}{c}390 \\
\pm 38 \\
(5)\end{array}$ & $\begin{array}{l}346 \\
\pm \text { II } \\
(7)\end{array}$ & $\begin{array}{r}405 \\
\pm 25 \\
(2)\end{array}$ & $\begin{array}{l}330 \\
\pm 10 \\
(2)\end{array}$ & 一 \\
\hline Cumberland A & $\begin{array}{r}286 \\
\pm \quad 18 \\
(5)\end{array}$ & $\begin{array}{r}3^{60} \\
+110 \\
(2)\end{array}$ & 400 & $\begin{array}{r}414 \\
\pm 31 \\
(5)\end{array}$ & & $\begin{array}{r}407 \\
\pm 47 \\
(7)\end{array}$ \\
\hline
\end{tabular}

Each entry gives the mean, below that the standard error of the mean, and below that again, in parentheses, the number of analyses in the group.

* Omitting one value of 920 .

$\uparrow$ Omitting one value of 890 .

\section{Variations with age in childhood, adolescence and adult life in England}

Fortunately the three largest groups of adult bones, from London and the southeast, Thames Valley and Cumberland $A$, allowed it to be established that there was no significant change in $\mathrm{Sr}$ level with age in adult life (Table 2). It was concluded that the means for the other smaller groups could be taken as valid estimates of adult levels.

When the data over the age range $2+$ years to 20 years were combined it can be seen from six of seven comparisons (Table I) that the means were not different from 
the adult means. The exception was Cumberland $A$. When the data were divided up into the ranges from $2+$ to 9 , from 10 to 14 and from 15 to 20 years it is clear that there were few analyses on bones from adolescents and from those whose skeletons had just stopped growing except from the Midlands and the south-east areas. Here it

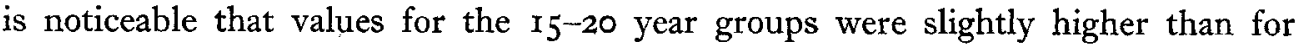
younger or older ages (though not significantly so). Half of the Midland specimens in the group from $2+$ to 20 years came from cases of sudden accidental death and conclusions may therefore be taken to refer to normal bone.

In each area except Cumberland $A$ the mean for the age range from 2 to 9 years was closely similar to that for adults. The two areas of Lancashire might be thought to show differences but these are in opposite directions. The broad conclusion is that there is little if any change in the ratio of stable $\mathrm{Sr}$ to $\mathrm{Ca}$ in bone after early childhood. Cumberland $\mathrm{A}$ is a clear exception, and it is noteworthy that the rise in Sr there appears to occur after the skeleton has ceased growing (Table 2).

\section{Scotland}

There were differences between different areas of central (lowland) Scotland (Table 3). (Only one of the Lanarkshire results came from the southern uplands in that county, see p. I6.) The highest values were found in eastern Stirlingshire, but there was insufficient evidence to show whether or not Edinburgh values were similar. The perinatal means in Glasgow and Lanarkshire were lower than any English mean.

Results for children in Inverness and northern Scotland were as high as for those in Stirlingshire and Midlothian (Table 2) and almost as high as for children of the same ages in south-east England.

\section{Wales}

North Wales (Flintshire and Denbighshire) had the lowest values for perinatal bones (Table 3). The values at older ages were correspondingly low and almost identical with those from the adjoining English county of Shropshire.

The perinatal values in south Wales were definitely higher than in north Wales (Table 3) and, when they were plotted on a map (Fig. I), it seemed as if the values in some of the hilly (mining) areas were appreciably higher than elsewhere in these hills or than in coastal areas. Since it was the results that suggested a geographical factor, but no objective means was known to me for choosing one or other method of grouping the data, the values for all these mining areas together are given in Table 3 and Fig. 2.

There were scattered data for perinatal bones from west and central Wales, both rural areas. The values from central Wales gave a mean value higher than anywhere else in Great Britain, higher even than in Carlisle, contrasting with the mean for west Wales which was in the lowest quartile (Table 3). All the other group means in south Wales lay between these two extremes (Fig. I and Table 3). These maximum values from central Wales were obtained only about 80 miles away from the region of north Wales where minimum perinatal values were found. In each area there was an anomalous value characteristic of the other area (Table 3 , second and fifth footnotes). 
हूँ

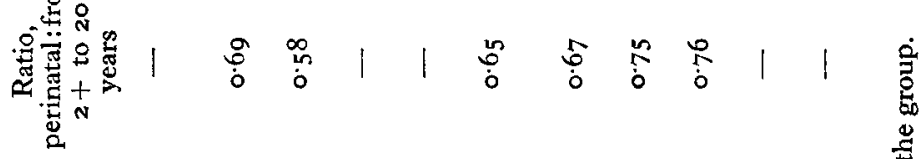

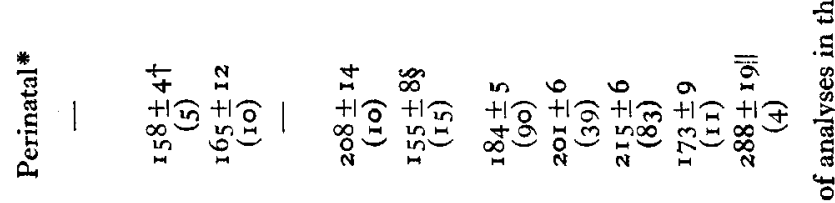

焉

$\frac{\sqrt{3}}{\frac{\pi}{0}}$

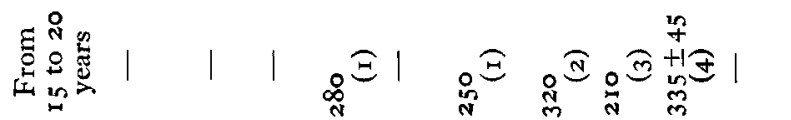

.ミ

so

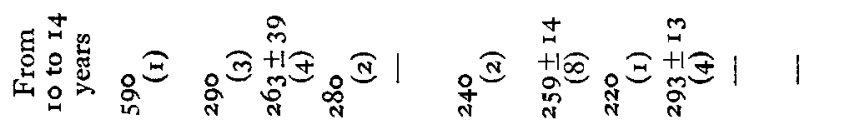

8

8ิ

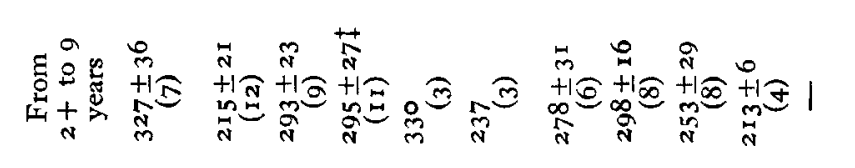

3

จ

.5

के

$\frac{\pi}{3}$

官

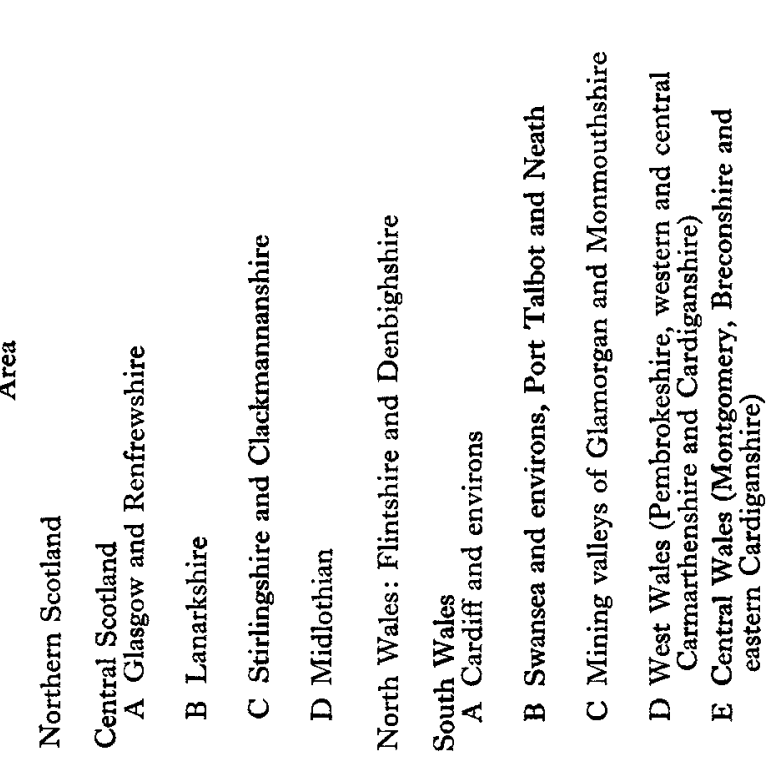




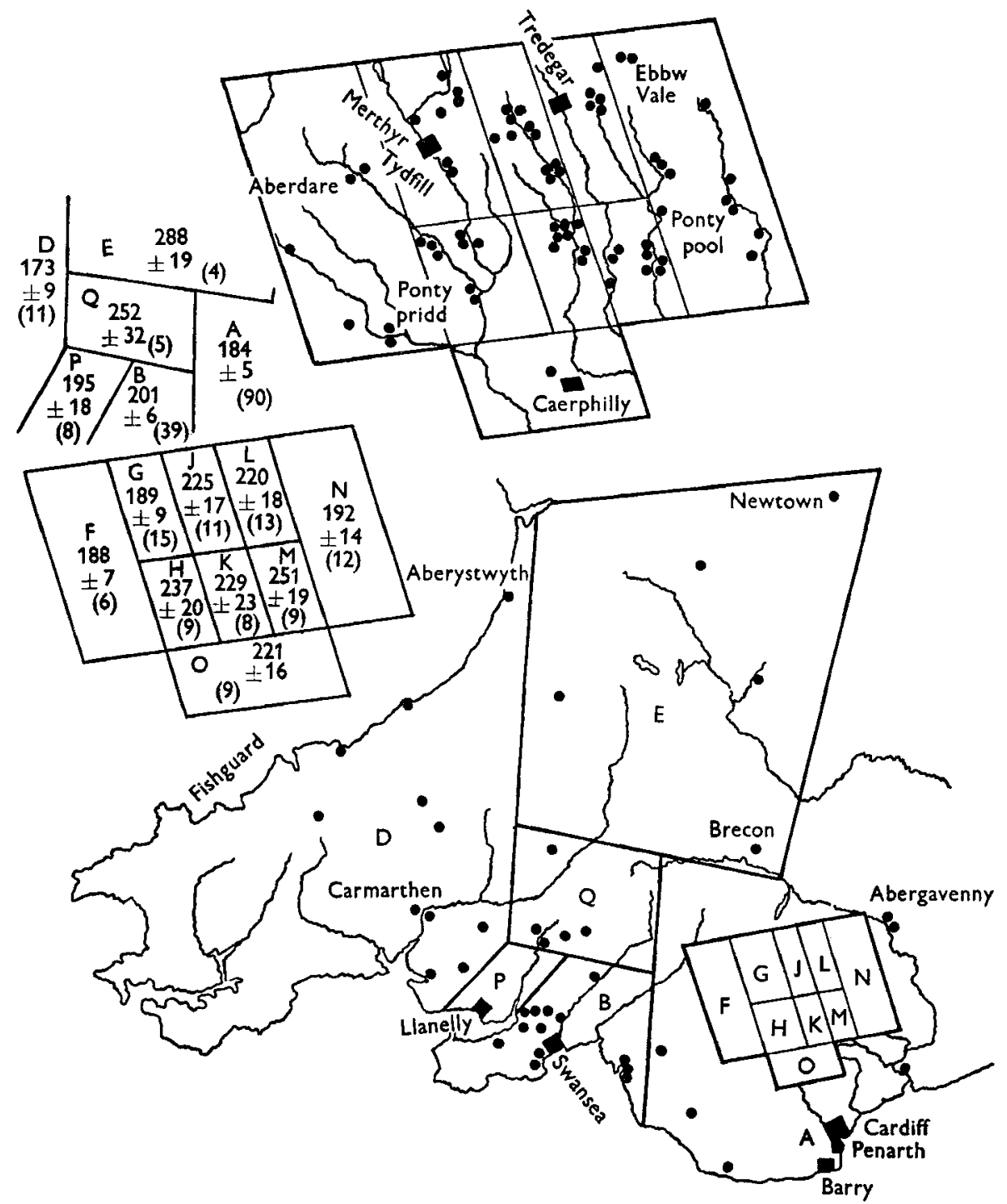

Fig. I. Map of south Wales showing origin of perinatal bone specimens and divided into different areas to reveal differences in mean levels of stable $\mathrm{Sr}$ in bone $(\mu \mathrm{g} / \mathrm{g} \mathrm{Ca})$. Each point represents one analysis. The black rectangles show localities providing eight or more analyses each. Area $\mathrm{C}$ of Table 3 is subdivided into areas $\mathrm{F}-\mathrm{O}$ and is shown on a larger scale in the inset at the top. Areas A, B, D and $\mathrm{E}$ are as in Table 3 . The values for stable $\mathrm{Sr}$ are given on the top left hand of the figure and each value for stable $\mathrm{Sr}$ is a mean for the area with its standard error below, and below that again, in parentheses, the number of analyses in the group.

\section{Variation in the first 2 years of life}

Perinatal values averaged about two-thirds of values for adults or individuals aged from $2+$ to 20 years. An attempt has been made to discover when the perinatal values reach these higher adult levels, but the geographical variation already noted made it necessary to consider each area separately. For this reason no values were available 
for some particular age groups and the numbers in any one group were usually small. However, if the same pattern of change is seen in many different areas then it is likely that the pattern really exists even if in each separate geographical area there may have been no statistically significant difference between the relevant age groups.

All the data for infants and children from nine different areas of the United Kingdom are plotted in Fig. 2, divided into age groups as shown. Individual results are plotted as separate points unless there were at least four values in an age group, when means \pm SE were calculated and shown by bars. Only for Lanarkshire, the Midlands, the
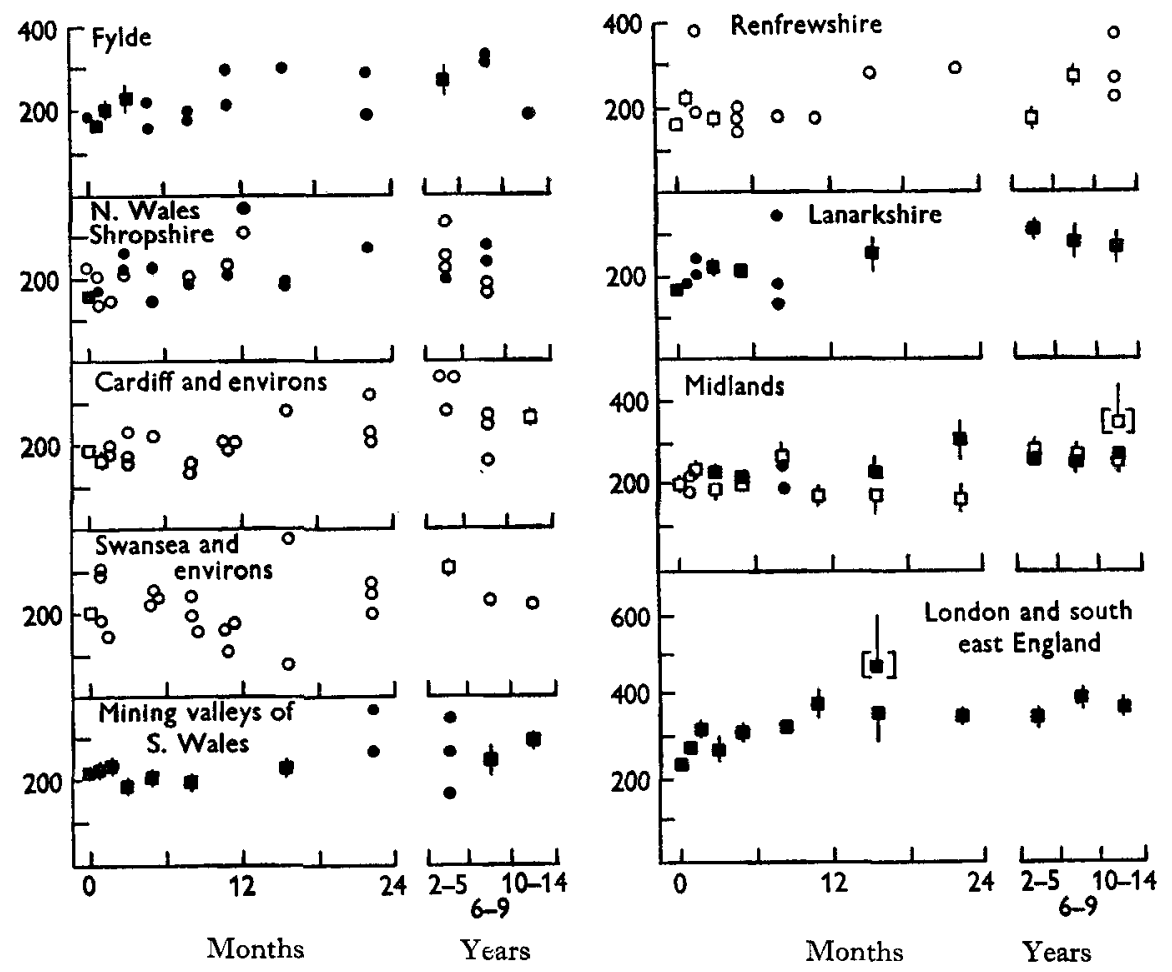

Fig. 2. Change with age in stable $\operatorname{Sr}(\mu \mathrm{g} / \mathrm{g} \mathrm{Ca})$ in bone in nine different areas of the United Kingdom. Where sufficient data exist mean values with their standard errors are shown by square symbols. Otherwise each point indicates an individual analysis. Because there are no perinatal data from Nottinghamshire and Leicestershire the data from the Midlands are not pooled but different symbols are used for Nottinghamshire and Leicestershire (closed) and for Birmingham and Warwickshire (open). Two points are plotted for the $13-18$ months group in the diagram for London and the south-east. The square brackets show the group mean when a single extreme value of 900 is included (see p. 22). Similarly square brackets around other means show that an extreme value has been included (cf. Table I, last footnote).

mining valleys of south Wales and for London and south-east England were the analyses numerous enough for group means to be commonly available. The data from the Midlands and the south-east may be intrinsically more heterogeneous than from the other seven areas, partly because the areas are very much larger. However heterogeneity was doubtless also important in south Wales (cf. Fig. I).

The two diagrams of Scottish data suggest that the Sr level does not rise until 
after the Ist year of life: the apparent rise in Lanarkshire early in the ist year is offset by an apparent fall in Renfrew. Similarly, there is no evidence in the three diagrams from south Wales of a rise during the first 12 months of life; indeed there is a suggestion of a fall to a minimum in the second half of the ist year. Where analyses are available, in the Cardiff and mining valley areas, there appears to be a progressive rise from the nadir at from 7 to 9 months to adult or nearly adult levels in the second half of the and year of life. In north Wales and in the Fylde there may be an initial rise

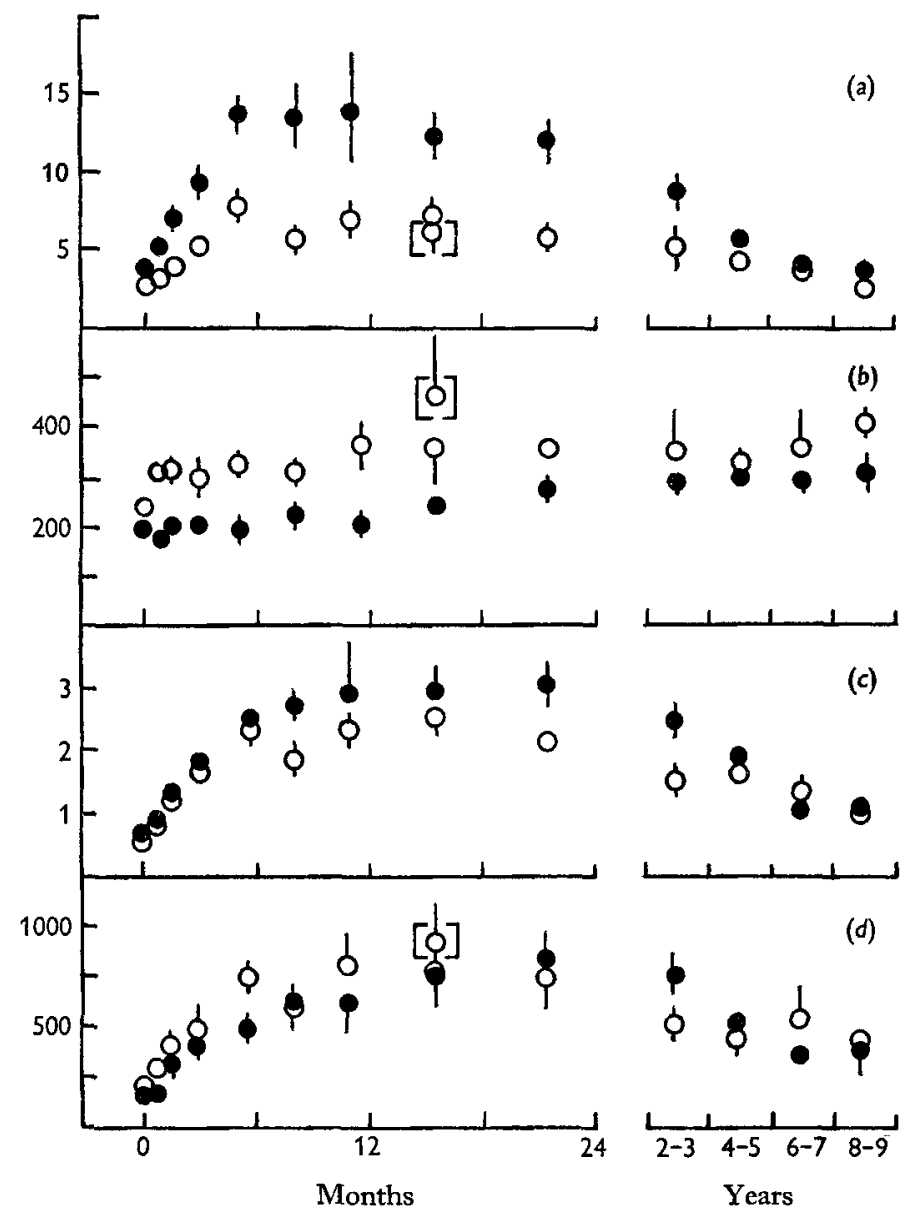

Fig. 3. Comparison for the 2-year period, rg6o second quarter to r 962 first quarter inclusive, of data from London and the south-east and from the rest of England, Scotland and Wales combined (see p. 22). (a) Specific activity of ${ }^{90} \mathrm{Sr}$ in bone (pc/mg stable Sr); (b) stable Sr $(\mu \mathrm{g} / \mathrm{g} \mathrm{Ca})$ in bone; $(c){ }^{90} \mathrm{Sr}(\mathrm{pc} / \mathrm{g} \mathrm{Ca})$ in bone; $(d)$ product of $(b)$ and $(c)$. $O$, London and southeast; - , rest of United Kingdom. Square brackets have the same significance as in Fig. 2.

during the first 3 months of life (see penultimate footnote, Table 3 ) but not subsequently. The data are scanty, and adult levels may be reached by the second half of the and and the second half of the Ist year respectively. Perinatal data are available from only part of the Midlands, and in the diagram Birmingham and Warwickshire 
are distinguished from Nottinghamshire and Leicestershire. There is no sustained rise in either zone until the second half of the 2nd year or later.

The picture from London and the south-east is quite different from that of the other eight areas. There is a progressive increase in Sr levels from the Ist week of life, so that adult values are reached by 10-12 months of age. Thereafter mean levels fluctuate little. The apparent peak in the $13-18$ month group is due entirely to a single value of $900 \mu \mathrm{g} / \mathrm{g}$. If this value is excluded, the $\mathrm{I} 3-18$ month mean lies between the means for the 10-12 and 19-24 month groups (Fig. 2).

London and the south-east is an area with a population of many millions and, if there were systematic differences in the origin of bone samples in the different age groups, it might just be possible that the rise in stable $\mathrm{Sr}$ during the first $\mathrm{I} 2$ months of life (Fig. 2) is an artifact and the result of geographical non-homogeneity within the area. No evidence was found in support of this suggestion.

The same basic data reviewed here were also considered by Bryant \& Loutit (1964). A comparison of their Fig. 3 (in which all the analyses in an age group were combined) with my Fig. 2 (in which geographical distinctions have been made) shows that geographical differences need to be taken into account when considering the physiological implications of changes in stable $\mathrm{Sr}$ levels in bone.

\section{Correlation of radioactive and stable strontium concentrations in bone}

The amount of ${ }^{90} \mathrm{Sr}$ taken up into bone salt must depend on the amount in the diet (food and drink), and there are known to be geographical differences within the United Kingdom in the ${ }^{90} \mathrm{Sr}$ content of milk for example (Agricultural Research Council Radiobiological Laboratory, 1959). Since there are striking geographical differences in stable $\mathrm{Sr}$ levels in bone, as shown in this paper, a correlation was sought between the concentration of the radioactive and the stable isotopes. One difficulty in attempting to establish such a correlation is that the amount of fallout has been varying from year to year, and another is that bone analyses over any short period of time from any one geographical area are inevitably few in number. However, during the period from the second quarter of 1960 to the first quarter of 1962 inclusive, ${ }^{90} \mathrm{Sr}$ levels in fresh cow's milk were fairly constant in each zone of milk production (Agricultural Research Council Radiobiological Laboratory, I962), and there seem to have been enough bone specimens from individuals dying in the same 2-year period to justify an attempt to use the data.

Fig. $3^{a}$ gives the ratio of ${ }^{90} \mathrm{Sr}$ to stable $\mathrm{Sr}$, the specific activity, in bone samples over the age range from stillbirths to 9 years. Since there was a difference between London and the south-east and all other areas in the rate of change of stable Sr during infancy (Fig. 2) results are shown separately for London and south-east England and for the rest of England, Scotland and Wales combined, omitting only results from the high $\mathrm{Sr}$ zone of northern England and the perinatal results from central Wales. One-third of the analyses in this combined group came from Lancashire and Cheshire, one-third from north and south Wales and one-quarter from the Midlands.

In each group there was a progressive increase in specific activity of $2 \frac{1}{2}$ - to 3 -fold in the first 6 months of life, a plateau from 7 to 24 months and then a decline. However, 
in the south-east area with high stable $\mathrm{Sr}$ levels the specific activity was always lower than in the rest of the United Kingdom, at the plateau age by a factor of about two. The values for children from 2 to 9 years of age show a quantitatively smaller geographical difference, but data on fallout in these older children are inevitably difficult to interpret. The rate of bone remodelling decreases as the skeleton grows in size, and the older the child the less closely does the composition of its bone salt reflect the composition of the current diet. Stable $\mathrm{Sr}$ in diet has presumably not varied greatly so that $\mathrm{Sr}$ levels in bone show little secular change. Fallout of ${ }^{90} \mathrm{Sr}$, however, has varied greatly and began to be appreciable in the United Kingdom only since 1956 when the 8- to 9-year-olds of Fig. 3 were already from 3 to 5 years of age.

If stable $\mathrm{Sr}$ and ${ }^{90} \mathrm{Sr}$ are inversely correlated with each other in bone salt, the product of the two ratios, of stable $\mathrm{Sr}$ to $\mathrm{Ca}$ and of ${ }^{90} \mathrm{Sr}$ to $\mathrm{Ca}$, would be relatively independent of the value of either. Fig. $3 d$ shows that there is indeed less geographical difference in the value of this product than in the specific activity (Fig. $3 a$ ), or in the levels of stable $\mathrm{Sr}$ or ${ }^{90} \mathrm{Sr}$ (Figs. $3 b$ and $c$ ), suggesting that the levels of these two isotopes in bone are indeed inversely proportional to each other.

This is a somewhat surprising finding since the amount of stable $\mathrm{Sr}$ in children's food would be expected to depend on the stable $\mathrm{Sr}$ available in the soil in those regions from which their food comes, whereas the amount of ${ }^{90} \mathrm{Sr}$ would be expected to depend primarily on the amount of fallout deposited in rain. There is no obvious environmental reason why these two should be correlated at all. Regional differences in the ratio of ${ }^{90} \mathrm{Sr}$ to $\mathrm{Ca}$ in milk are not greater than $40 \%$ above or below the weighted national average (Agricultural Research Council Radiobiological Laboratory, 1959), and the differences in the ratios in milk between the two groups illustrated in Fig. $3 c$ may well be much less than this. London and the south-east are supplied with milk produced in various parts of Great Britain, and this milk has a composition fairly close to the national average simply because it is a mixture. Milk produced in the Midlands has a ${ }^{90} \mathrm{Sr}$ : Ca ratio close to the national average. Although the ratio ${ }^{90} \mathrm{Sr}: \mathrm{Ca}$ in milk produced in Wales is $40 \%$ higher than the national average, the ratio in milk produced in the north-west (mainly Lancashire and Cheshire) is less than the national average, and the pooled data in Fig. 3 therefore come from a population whose milk (by and large) will have been fairly near to the national average. The effect of regional differences in fresh milk will be additionally reduced in proportion to the amount of dried milk used in infant feeding.

Differences in the ${ }^{90} \mathrm{Sr}$ levels in fresh milk cannot be the only factor concerned when infants begin to take a mixed diet, and something else must be looked for to account for the geographical differences over the age range from 7-9 months to 2-3 years of age (Fig. $3 a$ and $c$ ). It seems necessary to assume either that there is some metabolic reason for an inverse correlation between the concentrations of stable $\mathrm{Sr}$ and radioactive $\mathrm{Sr}$ in bone (for which there is no physiological evidence at present); or, if the concentrations are not metabolically correlated, that infants and children outside south-east England consume articles of food other than fresh milk with a relatively high content of ${ }^{90} \mathrm{Sr}$; or both factors could operate together. 


\section{Heterogeneity in perinatal samples according to season of year and cause of death}

The numbers of perinatal specimens (stillbirths and deaths within the Ist week of life) from some districts were so large that it was possible to find significant heterogeneities. For instance, the stable Sr levels in south Wales seem to have shown a IO-I $5 \%$ decrease over the 6 years during which observations have been accumulated (Table 4). The reason is not clear, though the hospitals from which samples have been obtained and the pathologists concerned in sample collection have not been the same throughout.

Table 4. Secular changes in stable Sr levels in perinatal bone (stillbirths and deaths within the Ist week)

\begin{tabular}{|c|c|c|c|c|}
\hline Area & Period & $\begin{array}{c}\text { Mean } \\
\text { with its } \\
\text { SE }\end{array}$ & $\begin{array}{l}\text { No. of } \\
\text { specimens }\end{array}$ & $\begin{array}{l}P \text { value of } \\
\text { comparisons }\end{array}$ \\
\hline \multirow[t]{2}{*}{ Swansea and environs } & $\begin{array}{l}\text { I957 to I } 960 \text { first } \\
\text { quarter }\end{array}$ & $207 \pm 7$ & 24 & \multirow[t]{2}{*}{$0.10<P<0.20$} \\
\hline & $\begin{array}{l}1960 \text { second quarter to } \\
1962 \text { first quarter }\end{array}$ & $190 \pm 9$ & I 5 & \\
\hline \multirow[t]{2}{*}{ Cardiff and environs } & $\begin{array}{l}1957 \text { to } 1959 \\
\text { I } 96 \text { I first quarter to } \\
1962 \text { first quarter }\end{array}$ & $\begin{array}{l}205 \pm 10 \\
188 \pm 8\end{array}$ & $\begin{array}{l}22 \\
26\end{array}$ & \multirow[t]{2}{*}{$P<0.0 \mathrm{I}$} \\
\hline & $\begin{array}{l}\text { 1962 second quarter to } \\
1963 \text { first quarter }\end{array}$ & $171 \pm 8$ & 42 & \\
\hline \multirow[t]{2}{*}{$\begin{array}{l}\text { London and south-east } \\
\text { England }\end{array}$} & $\begin{array}{l}\text { 1 } 956 \text { to I } 960 \text { first } \\
\text { quarter }\end{array}$ & $227 \pm 7$ & 46 & \multirow[t]{2}{*}{ Not significant } \\
\hline & $\begin{array}{l}\text { I } 960 \text { second quarter to } \\
1962 \text { first quarter }\end{array}$ & $243 \pm 10$ & 39 & \\
\hline
\end{tabular}

In one area, Blackpool and the Fylde, specimens were selected by one pathologist and came from one hospital. Nearly roo samples from the second quarter of 1960 to the second quarter of 1962 inclusive were analysed, and there seems to have been not only a seasonal variation but also a difference according to the mode of death (Table 5). Babies dying in the two winter quarters had lower mean values than those dying in the two summer quarters for both stable $\mathrm{Sr}$ and ${ }^{00} \mathrm{Sr}$ and babies dying with serious congenital defects usually showed lower values of stable Sr than those without these lesions. Both these conclusions seem as true of babies dying after the immediate perinatal period as of babies dying within $48 \mathrm{~h}$ of birth, but it should be noted that there are not many analyses for babies more than 2 days old without serious congenital defects.

It has not been possible to make similar comparisons within data from other centres and it is not inconceivable that these observed differences in the Fylde were due to some other factor or factors than the two chosen for analysis, season of the year and mode of death. Whatever the reasons for this heterogeneity it is clear that too much weight should not be placed on deductions from mean values for groups quoted in this paper or indeed from similar group means in the literature.

In specimens coming from the Fylde the lowest stable $\mathrm{Sr}$ values were found in babies dying between 7 and 30 days after birth (Table 5). It is tempting to imagine that these babies, with serious congenital defects, failed to thrive, that their food intake was inadequate, and that they were at least partly deficient in phosphorus. Babies 


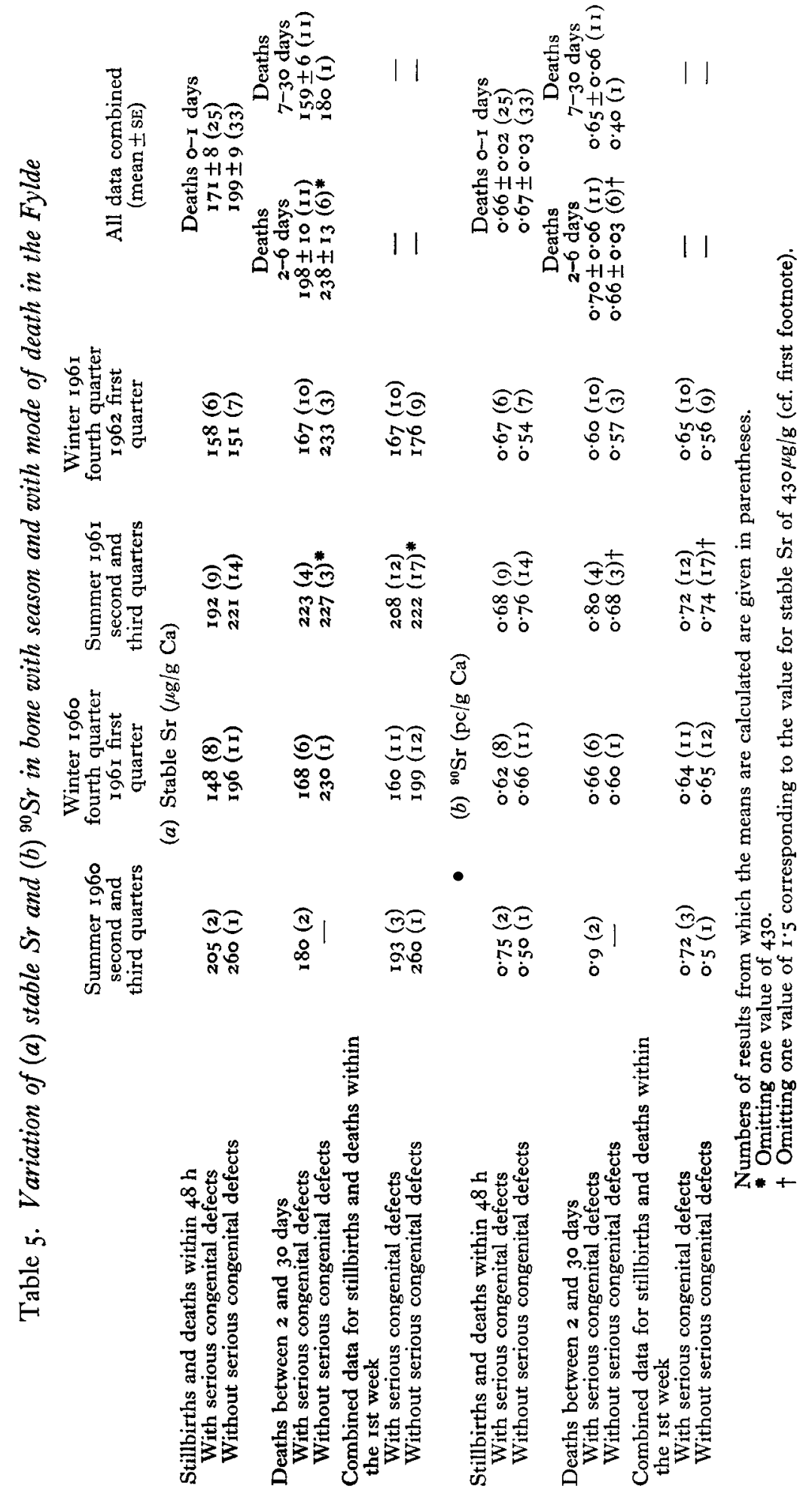


from 6 to 8 days old on a lower $P$ intake were in negative stable $\mathrm{Sr}$ balance whereas on a higher $\mathrm{P}$ intake stable $\mathrm{Sr}$ was retained (Widdowson, Slater, Harrison \& Sutton, I960; Widdowson, McCance, Harrison \& Sutton, I963). If this suggestion is true, stable $\mathrm{Sr}$ and ${ }^{90} \mathrm{Sr}$ are handled differently to some extent since there was no corresponding difference in ${ }^{90} \mathrm{Sr}$ levels in bone according to the mode of death (Table 5).

There was the same seasonal variation in ${ }^{90} \mathrm{Sr}$ as in stable $\mathrm{Sr}$, presumably for the same reason, a greater consumption by mothers in summer than in winter of vegetables which have higher stable $\mathrm{Sr}$ and ${ }^{90} \mathrm{Sr}$ levels than an average diet (Agricultural Research Council Radiobiological Laboratory, 1959).

\section{Perinatal Sr levels and placental discrimination}

By far the most numerous specimens were those from stillbirths and from babies dying within the first 7 days of life. The majority were presumptively normal, but some were premature and some died with gross congenital defects. The sample from one individual often consisted of several different bones and in a certain number the calvarium and spine were utilized and no femoral bone was included in the ashed specimen. It is not believed that the anatomical origin of the bones is of any moment from the present point of view.

Values for stable $\mathrm{Sr}(\mu \mathrm{g} / \mathrm{g} \mathrm{Ca})$ in bones coming from English areas are given in Table $I$ and from Welsh and Scottish areas in Table 3. In England the perinatal levels showed geographical differences in the same direction and of the same order as the levels in adults, but were always smaller. This was due to the well-known fact that the placenta does not transport $\mathrm{Ca}$ and $\mathrm{Sr}$ from the maternal to the foetal side with equal efficiency (Bryant \& Loutit, 196I) but shows some discrimination between these two chemically very similar elements.

An estimate of the degree of placental discrimination can be obtained by comparing the $\mathrm{Sr}$ : Ca ratio of perinatal and of adult bones. The ratio between these ratios (Table $\mathrm{I}$ ) ranges from 0.53 to 0.80 in different geographical areas, averaging 0.69 . The lowest value, 0.53 , is probably the most suspect, since in this area, Cumberland $A$, the adult mean for $2 \mathrm{I}-8 \mathrm{O}+$ years was so different from the observed values for younger age groups (Table 2): most children were born of mothers in the early twenties.

The adult means in most groups are based on rather small numbers and, since it has been noted that the mean for the age group from $2+$ to 20 years is about the same as the adult value, a more reliable estimate of the degree of discrimination may be derived by comparing the perinatal level with the mean for from $2+$ to 20 years. The four English values (Table $I$ ) range from 0.60 to $0.8 \mathrm{I}$ averaging 0.72 . Values for Wales and Scotland range from 0.58 to 0.76 (Table 2) averaging 0.71 and 0.63 , respectively. Overall it would appear that a value of about 0.7 is the best estimate from the data now presented of the ratio of stable $\mathrm{Sr}$ in bone ash in perinatal and in adult bones. The value of 0.6 given elsewhere (Loutit, 1963; Bryant \& Loutit, 1964) was derived without geographical differences in stable Sr levels being taken into account.

A value for this ratio can also be deduced from Australian data (Bryant, Moroney, Stevens \& Titterton, 1963 ). Bone levels of stable $\mathrm{Sr}$ in five different cities for babies from 0 to I month old were higher than in the United Kingdom, ranging from 290 to 
$520 \mu \mathrm{g} / \mathrm{g} \mathrm{Ca}$, but so were adult levels, $420-650 \mu \mathrm{g} / \mathrm{g}$. The ratio of values for babies from $o$ to I month old to adult values in different areas and seasons ranged from $0.5 \mathrm{I}$ to 0.84 with a mean for ten values of 0.69 in agreement with the British data.

The $\mathrm{Ca}$ and $\mathrm{Sr}$ in a stillborn infant must be wholly derived from the mother's plasma, which would be effectively true also for infants dying within the rst week of life. If the mother's plasma is in analytical equilibrium with the maternal skeleton then a comparison of infant and maternal bones will indicate the magnitude of any discrimination by the placenta. Analytical equilibrium will exist if either of two conditions applies: (1) the $\mathrm{Sr}$ of the maternal skeleton is all rapidly exchangeable with that in the maternal plasma, or (2) the diet of the mother has been constant on average in its ratio of $\mathrm{Sr}$ to $\mathrm{Ca}$ during the growth of her skeleton and the duration of her pregnancy. Since it is usually believed that the bone salt, including the $\mathrm{Sr}$, of the adult skeleton is subject to only slow turnover, it is the second condition which is relied on. If the mean dietary ratio of $\mathrm{Sr}$ to $\mathrm{Ca}$ has indeed been constant during the growth of a future mother's skeleton and thereafter, it is likely to have been constant for all individuals (in a given area) and therefore it is legitimate to use values obtained for males and non-pregnant females as estimates of the values in the maternal skeleton during pregnancy.

The ratio of perinatal bone to maternal bone will be a biased estimate of placental discrimination to the extent to which maternal plasma and maternal bone are not in equilibrium during pregnancy. The value for the ratio 0.7 obtained here is larger, implying a smaller discrimination, than the factor of about 0.5 derived from comparisons of levels of ${ }^{90} \mathrm{Sr}$ (from fallout) in the average national diet, in maternal plasma and in perinatal bone (Loutit, 1963). The difference in the two derivations is in the direction to be expected given the slow turnover of bone salt in the adult. Because of this the maternal skeleton cannot be in radioactive equilibrium with the maternal plasma.

A single example in fact exists in the British data where values from mother and child can be compared directly. Femoral bone from a 21-year-old woman who died from toxaemia of pregnancy contained stable Sr $240 \mu \mathrm{g} / \mathrm{g} \mathrm{Ca}$ and ${ }^{90} \mathrm{Sr} 0.36 \mathrm{pc} / \mathrm{g} \mathrm{Ca}$ and the pooled ash of several bones from her stillborn child contained stable Sr $210 \mu \mathrm{g} / \mathrm{g}$ $\mathrm{Ca}$ and ${ }^{90} \mathrm{Sr} 0.90 \mathrm{pc} / \mathrm{g} \mathrm{Ca}$. The stable $\mathrm{Sr}$ ratio is 0.9 , in agreement with the pooled data considered above, whereas the ${ }^{90} \mathrm{Sr}$ ratio of 2.5 shows clearly the lack of radioactive equilibrium.

\section{DISCUSSION}

Any conclusions to be drawn from analytical results depend in the first place on analytical reliability. The spectrographic method originally used for the determination of stable Sr was carefully checked (Bryant \& Loutit, I96I) and a later method gave indistinguishable results (Bryant et al. 1964).

The bone specimens came from a large number of hospitals but it is not believed that contamination was responsible for the observed geographical differences. When specimens of bone were obtained, they were placed in clean, new cellophane bags provided from the same central store to all collecting centres for storage and transport. Occasionally by chance bones in the same batch of specimens from one hospital came 
from individuals with widely differing domiciles and gave widely different analytical results but in agreement with the geographical area of domicile.

Another important question, if general conclusions are to be drawn from the results, is how representative the original bone specimens were. They were not selected on a deliberately planned basis, with the single exception of about 100 specimens from the London area in 1961 (Bartlett et al. I963), and, even if they had been, specimens from people who have died will not necessarily provide results representative of those who remain alive. Rather over half the adult specimens from the Thames Valley and London and the south-east were from cases of sudden death and these may probably be regarded as physiologically representative, if it can be assumed that arterial disease is not specifically correlated with the metabolism of bone salt. Rather more than half the specimens from individuals between 10 and 20 years of age in the Midlands and in the London area were from cases of accidental death and these can surely be regarded as definitely providing physiological information. It is with the younger children that there must be most doubt about the 'normality' of the specimens. For instance, onequarter of specimens from children between 4 and 24 months of age from London and the south-east were from individuals with hydrocephalus or other gross cerebral abnormalities. Congenital defect of the heart was an equally common cause of death in young children of a variety of ages. There is no need to assume more than indirect correlations with bone metabolism: even if prolonged under-or mal-nutrition altered the growth of bone more quickly and easily than the composition of bone salt, the level of dietary $\mathrm{P}$ in relation to the body's needs might affect $\mathrm{Sr}$ levels, as discussed later. Whatever the magnitude of any differences there may possibly be between the analysed specimens and the bones of healthy 'normal' individuals of the same age, and however important these may be when deductions are to be made about the rate of turnover of bone salt, it is to be expected that this source of bias will have been similar in all the different geographical areas and thus not in itself responsible for the observed geographical differences.

No particular correlation was found between categories of death and Sr levels except in perinatal specimens in which mean levels differed by about one-sixth between babies dying with or without serious congenital defects. In the same babies there was a seasonal difference of similar magnitude in both stable $\mathrm{Sr}$ and ${ }^{90} \mathrm{Sr}$. The bones of newborn children might well be more subject to short-term secular variation than the bones of older individuals, because the bones in the developing foetus would be expected to reflect corresponding variations in maternal diet. In Australia too, the values obtained for stable $\mathrm{Sr}$ in babies dying in July to December r96r were usually less than for January to June $196 \mathrm{I}$, but it is perhaps unexpected that there were similar seasonal differences in adult bone levels (Bryant, Moroney et al. 1963).

It may be objected that only small numbers of analyses are available in many of the groups in Tables I and 3. This is true although in some, like the adult groups from London and the south-east and from the Thames Valley, the numbers of specimens are enough to give standard errors of less than $5 \%$ of means of about $35 \% \mu \mathrm{g} / \mathrm{g}$. The combined data for the thirty adult specimens from the rest of England (excluding Cumberland) have a mean of $260 \mu \mathrm{g} / \mathrm{g}$, again with a standard error of less than $5 \%$. 
Thus there can be no question that real geographical differences exist, although small numbers of specimens from widely scattered areas necessarily provide an inadequate basis for detailed study.

Granted that geographical differences in a relatively small country have been clearly established, it is tempting to look for environmental differences in stable $\mathrm{Sr}$ levels, in drinking water or in milk, for example, which might be correlated with differences in bone levels. However, if it is accepted that the bone salt of the adult skeleton undergoes little physiological turnover, then what needs to be correlated with analyses for individuals $40-80$ years old may be the factors which were in existence a long time ago, perhaps even 40-80 years ago. Present-day analyses of drinking water or of milk may be misleading, not merely irrelevant: the distribution and pooling of milk supplies have been revolutionized since the Milk Marketing Board came into existence $3 \mathrm{I}$ years ago, and the distribution of other foodstuffs must have been markedly altered since the First Great War by the development of the lorry and of intensive market gardening. Considering the degree of social mobility of the population of Great Britain, it is perhaps additionally surprising that consistent geographical differences were found at all.

Correlations of analyses for individuals under 20 years of age should be much less open to secular error since their whole lives were postwar and differences in the diet of infants and children between different social classes and different geographical areas may not have been so great as formerly. However, except for one area, Carlisle, the same geographical differences were seen in the age range 2-20 years as in adults; Carlisle was the only area where levels in adults and teenagers were clearly not the same.

The most striking geographical difference and the one with the least obvious explanation is the way in which the ratio of stable $\mathrm{Sr}$ to $\mathrm{Ca}$ in bone increased progressively from birth in south-east England but remained nearly stationary in all other areas during the ist year or so of life. It has commonly been assumed that tissue levels of stable $\mathrm{Sr}$ depend merely on overall levels in food and drink and on physiological factors which affect the discrimination between $\mathrm{Sr}$ and $\mathrm{Ca}$. To explain the difference between south-east England and all other areas it would then be necessary to assume that dietary levels of stable $\mathrm{Sr}$ were quite different since there can hardly be marked physiological differences between children in different parts of the same small country with a high overall standard of physical well-being. The dietary levels of stable Sr would have to be such that in the rest of England, Wales and Scotland the change in level with change in composition of the diet during the Ist year of life just neutralized the changes in physiological discrimination in intestine and kidney which have been believed to occur at this time.

Not many analyses have been reported of the ratio of stable $\mathrm{Sr}$ to $\mathrm{Ca}$ in milk produced in the United Kingdom. After allowing for seasonal variations, the data (Agricultural Research Council Radiobiological Laboratory, 1960, 196r $a, b$ ) show that the lowest annual averages of $310-320 \mu \mathrm{g} / \mathrm{g}$ were found in the north-west milkproducing zone (which includes Lancashire) and the west Midlands zone (which includes Shropshire and Worcestershire) whereas the highest level of $44^{\circ} \mu \mathrm{g} / \mathrm{g}$ was in 
the northern milk-producing zone (including Cumberland, Northumberland and the North Riding of Yorkshire). The south and south-east zone (which includes much of the Thames Valley and London areas of Table I) was intermediate with $400 \mu \mathrm{g} / \mathrm{g}$. Apart from the discrepancy in Devonshire (with low bone levels but included in the far-west milk zone with high milk Sr), the geographical differences in milk levels of stable $\mathrm{Sr}$ are well correlated with the geographical differences in bone levels in childhood, adolescence and adult life (Table $\mathrm{r}$ and $\mathrm{p}$. I4). This correlation presumably reflects a correlation between levels in diet and in bone but only in an indirect fashion, since after the ist year of life only one-seventh to one-eighth of the stable Sr intake comes from fresh milk and milk products (Agricultural Research Council Radiobiological Laboratory, $1959,196 \mathrm{r} b$ ). Further, the marketing arrangements for fresh milk allow some flexibility in the source of supply to some areas.

Nearly $40 \%$ of the daily intake of stable $\mathrm{Sr}$ in the national diet is believed to come from the chalk which is added to flour from which bread is baked (Agricultural Research Council Radiobiological Laboratory, 1959). No information is available about possible regional variations.

Water for drinking and cooking accounts for one-seventh of the intake, so that very large variations in $\mathrm{Sr}$ level in water would be needed to account for the observed differences in bone level of more than $50 \%$ (Tables I and 3, Fig. 2). However, these geographical differences are maximal during the Ist year of life, and so little is known about the Sr level of the diet of infants under 12 months of age (Bryant \& Loutit, 1961) that discussion about the reasons for the observed differences can only be discursive and hypothetical. The 'national diet' is in any event an abstract idea, and it may be noted that analysis of the excreta of a number of human subjects, from 3 to $5^{\circ}$ years of age, all in Social Class I and living in the Thames Valley area of Table I, showed that their daily intake of stable $\mathrm{Sr}$ must have been appreciably higher than suggested by the national statistics (Harrison, Raymond \& Tretheway, 1955; Bedford, Harrison, Raymond \& Sutton, 1960). Urinary and faecal excretion together amounted to I-3 mg stable Sr per day in four children from 9 to I 4 years old and 2-3 $\mathrm{mg}$ per day in three adults, whereas the average 'national diet' provides I $\mathrm{mg}$ more or less (Bryant \& Loutit, I96I). Since the Thames Valley area of Table $I$ is an area with levels of stable $\mathrm{Sr}$ in bone well above the national average, these metabolic studies may be thought to confirm a correlation between levels in bone and in diet.

One corollary of the findings reported here is that it may be hazardous to use changes in stable $\mathrm{Sr}$ levels with age as evidence for changes in such physiological phenomenons as discrimination in intestinal absorption between $\mathrm{Ca}$ and $\mathrm{Sr}$ or in rates of turnover of bone salt in the skeleton. Similarly, the geographical differences in levels of ${ }^{90} \mathrm{Sr}$ and in its specific activity will need to be taken into account if changes in ${ }^{90} \mathrm{Sr}$ levels with age are to be used to deduce something about the metabolism of bone salt and the turnover of the skeleton, as in the tentative suggestions of Bryant \& Loutit (196r, 1964) and Loutit (1963).

It may be useful to mention the possibility that changes in bone levels of $\mathrm{Sr}$, stable or radioactive, could occur without changes in dietary levels of $\mathrm{Sr}$ or changes in intrinsic physiological discrimination. The level of $\mathrm{P}$ in the diet has been shown to 
control the Sr balance in the 6-8 days old human infant (Widdowson et al. I960, I963) and the retention of $\mathrm{Sr}$ in the bones of experimental animals (literature cited by Kostial, Lutkic, Gruden, Vojvodic \& Harrison, I963). Animal experiments have also shown that a reduction in dietary $P$ beginning several weeks after the incorporation of Sr into bone can lead forthwith to a loss of Sr from the bone continuing until after the dietary $\mathrm{P}$ has been restored to its former level (van Putten, 1962). If it be generally true that when the available $P$ in the diet is relatively deficient, the body burgles its bones for their phosphate (cf. Loutit, I960), then the fact that there is renal discrimination inevitably entails a difference in Sr levels in bone when there are sufficiently large differences in the levels of $\mathbf{P}$ in the diet. The reason is that the more rapid the turnover of bone salt the greater will be the renal leak of $\mathrm{Sr}$ as compared with $\mathrm{Ca}$. Is it possible that the diet of infants less than $I$ year old in the relatively prosperous south-eastern area of England is generally richer in $\mathrm{P}$ than elsewhere? The lower perinatal mortality in the south-east than in the north or west in $195^{8}$ was correlated in a number of ways with differences in prosperity and in physiological attributes (Illsley \& Kincaid, I963). Human milk contains less P than the milk used for bottlefeeding and a low incidence of breast feeding in the south-east might help to account for the rise in bone Sr during the first few weeks and months of life in babies living in this region (Fig. 2). Bone levels must also be affected by the amount of $\mathrm{Sr}$ in the diet, and analysis of excreta for $\mathrm{P}, \mathrm{Ca}$ and $\mathrm{Sr}$ in different areas of the country and of children of different social classes might provide a direct test of the relative importance of these various factors.

\section{SUMMARY}

I. A re-asssessment has been made of published data of other workers on $\mathrm{Sr}$ and ${ }^{90} \mathrm{Sr}$ in human bone. In different parts of Great Britain the mean ratio of stable Sr to $\mathrm{Ca}$ in adult human bones ranged from 240 to $475 \mu \mathrm{g} / \mathrm{g}$. Extreme values were found even as close as 40 miles apart (Carlisle $v$. Westmorland).

2. Perinatal levels of stable Sr were correlated with adult levels. An estimate of placental discrimination may be derived from the ratio, perinatal level: adult level of about 0.7 .

3. The concentration of stable $\mathrm{Sr}$ in bones of children from 2 to 5 years old or more was not demonstrably different from that of adults except in one area, Carlisle. With the striking exception of London and south-east England the change from perinatal to adult levels occurred in the 2 nd year of life: there was no particular change during the first 9 months or so. In London and south-east England the pattern of change with age was quite different: there was a progressive rise in Sr level from shortly after birth to the end of the ist year by which time adult levels were reached. It is concluded that geographical differences need to be taken into account when making physiological deductions about turnover of bone salt from changes with age in the level of stable Sr.

4. When children in the south-east of England and the rest of the United Kingdom were compared, there seemed to be a broad inverse correlation between levels of stable $\mathrm{Sr}$ and of ${ }^{90 \mathrm{Sr}}$.

5. Detailed analysis of perinatal results from one area suggested that the level of 
stable $\mathrm{Sr}$ in bone was somewhat higher in summer than in winter and somewhat higher in anatomically normal babies than in babies dying with gross congenital defects. ${ }^{90} \mathrm{Sr}$ showed the seasonal change only.

This survey would not have been possible without the detailed records which accompanied the bone samples and which were provided by the many pathologists who arranged for their collection. I am grateful to all of them and particularly to Dr P. H. Harvey, then of Victoria Hospital, Blackpool, whose admirable summaries made it possible to analyse for differences according to season and mode of death. I am. especially grateful to Dr J. F. Loutit, FRS, Chairman of the Management SubCommittee on Monitoring of the joint ARC/MRC/DC Committee on Biological Problems (non-medical) of Nuclear Physics for allowing me full access to all the records and for his criticisms as well as his encouragement. Dr F. J. Bryant kindly checked the manuscript.

\section{REFERENCES}

Agricultural Research Council Radiobiological Laboratory (1959). Report ARCRL I.

Agricultural Research Council Radiobiological Laboratory (I960). Report ARCRL 2.

Agricultural Research Council Radiobiological Laboratory (I96Ia). Report ARCRL 3 .

Agricultural Research Council Radiobiological Laboratory (196 I b). Report ARCRL 4.

Agricultural Research Council Radiobiological Laboratory (I962). Report ARCRL 8.

Arden, J. W., Bryant, F. J., Henderson, E. H., Lloyd, G. D. \& Morgan, A. G. (1960). Atomic Energy Research Establishment, Harwell, Report AERE-R 3246.

Bartlett, B. O., Bryant, F. J. \& Loutit, J. F. (1963). In Medical Research Council Monitoring Report Series, no. 6, p. 8.

Bedford, J., Harrison, G. E., Raymond, W. H. A. \& Sutton, A. (1960). Brit. med. F. i, 589.

Bryant, F. J., Chamberlain, A. C., Morgan, A. \& Spicer, G. S. (1957). Atomic Energy Research Establishment, Harwell, Report AERE HP/R 2353.

Bryant, F. J., Cotterill, J. C., Henderson, E. H., Spicer, G. S. \& Webber, T. J. (1959). Atomic Energy Research Establishment, Harwell, Report AERE-R 2988.

Bryant, F. J., Henderson, E. H., Jenkins, W., Jury, R. V., Parker, A. \& Wordingham, M. L. (1962). In Medical Research Council Monitoring Report Series, no, 5, p. 2.

Bryant, F. J., Henderson, E. H., Jones, T. W., Lee, I., Lloyd, G. D. \& Wordingham, M. L. (196r). In Medical Research Council Monitoring Report Series, no. 2, p. 2.

Bryant, F. J., Henderson, E. H., Jury, R. V., Morton, A. G., Parker, A. \& Webber, E. R. (1963). In Medical Research Council Monitoring Report Series, no. 7, p. 4.

Bryant, F. J., Henderson, E. H., Jury, R. V., Morton, A. G., Parker, A. \& Webber, E. R. (1964). In Medical Research Council Monitoring Report Series, no. 8, p. 2.

Bryant, F. J., Henderson, E. H., Jury, R. V., Parker, A., Sweeney, B. \& Webber, E. R. (I963). In Medical Research Council Monitoring Report Series, no. 6, p. 2.

Bryant, F. J., Henderson, E. H., Lee, I., Lloyd, G. D. \& Webb, M. S. W. (I960). In Medical Research Council Monitoring Report Series, no. I, p. 2.

Bryant, F. J., Henderson, E. H., Lee, I., Parker, A., Sweeney, B. \& Webb, M. S. W. (1962). In Medical Research Council Monitoring Report Series, no. 4, p. 2.

Bryant, F. J., Henderson, E. H., Lee, I., Sweeney, B. \& Webb, M. S. W. (I96I). In Medical Research Council Monitoring Report Series, no. 3, p. 2.

Bryant, F. J., Henderson, E. H., Spicer, G. S. \& Webb, M. S. W. (1958). Atomic Energy Research Establishment, Harwell, Report AERE C/R 2583.

Bryant, F. J., Henderson, E. H., Spicer, G. S., Webb, M. S. W. \& Webber, T. J. (1959). Atomic Energy Research Establishment, Harwell, Report AERE C/R 2816.

Bryant, F. J. \& Loutit, J. F. (I96r). Atomic Energy Research Establishment, Harwell, Report AERE-R 3718.

Bryant, F. J. \& Loutit, J. F. (1964). Proc. roy. Soc. B, 159, 449.

Bryant, F. J., Moroney, J. R., Stevens, D. J. \& Titterton, E. W. (1963). Aust. F. Sci. $26,69$.

Fraser, R., Harrison, M. \& Ibbertson, K. (r96o). Quart. F. Med. 29, 85.

Graham, S., Lenihan, J. M. A., Macdonald, A. M. \& Warren, J. M. (I960). In Medical Research Council Monitoring Report Series, no. I, p. I3. 
Harrison, G. E., Raymond, W. H, A. \& Tretheway, H. C. (1955). Clin. Sci. r4, 681.

Illsley, R. \& Kincaid, J. C. (1963). In Perinatal Mortality: the First Report of the 1958 British Perinatal Mortality Strvey. Edinburgh: E. and S. Livingstone.

Jury, R. V., Webb, M. S. W. \& Webb, R. J. (1960). Analyt. chim. acta, 22, I45.

Kostial, K., Lutkic, A., Gruden, N., Vojvodic, S. \& Harrison, G. E. (I963). Int. F. Radiat. Biol. 6, 431. Loutit, J. F. (1960). Lancet, ii, I448.

Loutit, J. F. (1963). Proc. Nutr. Soc. 22, 140.

Thurber, D. L., Kulp, J. L., Hodges, E., Gast, P. W. \& Wampler, J. M. (1958). Science, $128,256$. van Putten, L. M. (1962). Int. F. Radiat. Biol. 5, 477.

Webb, M. S. W. \& Wordingham, M. L. (1963). Analyt. chim. acta, 28, 450.

Widdowson, E. M., McCance, R. A., Harrison, G. E. \& Sutton, A. (1963). Lancet, ii, 1250.

Widdowson, E. M., Slater, J. E., Harrison, G. E. \& Sutton, A. (I960). Lancet, ii, 94r. 